\title{
Influence of Temperature and Moisture on Seed Viability Period in Sunflower seeds
}

\author{
N. Nithya ${ }^{1 *}$, J. Renugadevi ${ }^{1}$, M. Bhaskaran ${ }^{1}$ and A. Johnjoel ${ }^{2}$ \\ ${ }^{1}$ Department of Seed Science and Technology, ${ }^{2}$ Department of Plant Genetic Resource, \\ Tamil Nadu Agricultural University, Coimbatore - 641003, Tamil Nadu, India \\ *Corresponding author
}

\section{A B S T R A C T}

\begin{tabular}{|l|}
\hline Ke y w or d s \\
$\begin{array}{l}\text { Sunflower, Cold } \\
\text { storage, Scanning } \\
\text { electron } \\
\text { microscope, Seed } \\
\text { health and seed } \\
\text { vigour. }\end{array}$ \\
\hline Article Info \\
\hline $\begin{array}{l}\text { Accepted: } \\
\text { 07 October } 2017 \\
\text { Available Online: } \\
\text { 10 December } 2017\end{array}$ \\
\hline
\end{tabular}

Keywords

Sunflower, Cold storage, Scanning electron microscope, Seed health and seed vigour.

Article Info

Accepted:

Available Online:

10 December 2017
A study to determine the optimum seed moisture content and storage temperature for sunflower seeds under cold storage at two different moisture content (6 and $8 \%)$ with three different temperature $\left(+5,-5\right.$ and $\left.-20^{\circ} \mathrm{C}\right)$ and seeds with same moisture content were stored in cloth bags for ambient conditions for ten months. Cold storage conditions in comparison to ambient conditions revealed that, the seeds stored at $-20^{\circ} \mathrm{C}$ with 6 per cent moisture content maintained the seed physiological qualities like germination and vigour index at higher level with minimum loss in biochemical parameters like protein and oil content and less reduction in the activities of dehydrogenase, catalase, peroxidase and lipoxygenase enzymes than the seeds under ambient storage. The supremacy of cold storage was also supported by structural study of seed coat changes through scanning electron microscope and seed health study.

\section{Introduction}

Sunflower is an important oil seed crop. It has a special place in food security and industry throughout the world. However, storage of sunflower seed needs more attention, since the seed characterised as poor storer. When oilseeds are not provided with proper storage condition, the quantity and quality losses might be increased.

Oilseeds contain more of polyunsaturated fatty acids which undergo rapid deterioration owing to lipid autooxidation and fungal activity (Roberts, 1972; Koostra and Harrington, 1969) which leads to faster deterioration. Seed deterioration is an in evitable process; it is associated with lot of physiological, biochemical and seed structural changes. Seeds of different plant species loose viability to a various degree even though they are kept at same storage conditions.

Once deterioration started it cannot be stopped but by maintaining the seed moisture content at optimum level and storage environment at dry and cool condition, the rate of deterioration process can be minimized. The fact was reported by many scientists that dry and cold conditions will 
increase shelf life of biological material; Seed moisture and storage temperature are the important factors which affect the quality and quantity of stored product (Sisman, 2005, Vijay et al., 2009). The basic objective of cold storage is to keep the storage temperature below the usual ambient temperatures, thereby minimizing the biochemical reactions, which leads to the maintenance of physiological quality and prevents insects and fungi development. Based on these aspects a study was carried out in sunflower seeds to determine the optimum seed moisture content and storage temperature to prolong the shelf life of sunflower seeds.

\section{Materials and Methods}

\section{Materials}

Freshly harvested sunflower seed cv.CO 4 obtained from, Department of Oilseeds, Tamil Nadu Agricultural University, Coimbatore formed the base material for the study.

The cold storage facility at Department of Plant Genetic Resources, TNAU, Coimbatore was utilized for the study. The laboratory studies were carried out in the Department of Seed Science and Technology, Tamil Nadu Agricultural University, Coimbatore during 2011-2012.

The seed with initial moisture content of 6 per cent were conditioned to moisture contents of 6 and 8 per cent increased by adding specified quantity of water. For increasing the seed moisture content, the quantity of water added was arrived by using the following formula (Gwinner et al., 1996).

RPMC - IPMC

Weight of water to be added $(\mathrm{g})=$

$100-\mathrm{RPMC}$

Where, RPMC - Required seed moisture content in percentage, IPMC - Initial seed moisture content in percentage. The seeds with 6 and 8 per cent moisture contents were vaccum packed in tri laminated aluminium foil pouches using the vaccum sealer model AUDIONVAC VMS 153 with a pressure of 0.95 bars and kept in the cold storage units maintained at temperatures of $+5,-5$ and $-20^{\circ} \mathrm{C}$ with relative humidity of the unit maintained below 25 per cent respectively. The seeds with the same moisture content packed in cloth bag and stored under ambient condition served as a check.

\section{Physiological parameters}

After ten days; number of total germinated seed, abnormal seedlings, length of seedlings, dry matter weight, viability percentage and vigour index was calculated.

\section{Biochemical parameters}

The electrical conductivity of the seed leachate was measured in an electrical conductivity meter and the conductivity of the leachate was expressed as $\mathrm{dSm}^{-1}$. The protein content was determined by the method of Alikhan and Young, (1973). Oil from sunflower seeds were extracted with petroleum ether $\left(40-60^{\circ} \mathrm{C}\right)$ in Soxhlet extractor for 6 hours and oil content expressed in percentage (Sadasivam and Manickam, 1995). Estimation of free fatty acid content was done by the method of Christiansen and Moore, (1961).

Catalase activity was measured by monitoring the decrease in absorbance at $240 \mathrm{~nm}$ in 50 $\mathrm{mM}$ phosphate buffer ( $\mathrm{pH}$ 7.5) containing 20 $\mathrm{mM} \mathrm{H} \mathrm{H}_{2} \mathrm{O}_{2}$. One unit of catalase activity was defined as the amount of enzyme that used 1 $\mu \mathrm{mol} \mathrm{H}_{2} \mathrm{O}_{2}$ per min. Peroxidase activity was measured by monitoring the increase in absorbance at $470 \mathrm{~nm}$ in $50 \mathrm{mM}$ phosphate buffer ( $\mathrm{pH}$ 7.0) containing $1 \mathrm{mM}$ guaiacol and $0.5 \mathrm{mM} \mathrm{H}_{2} \mathrm{O}_{2}$. One unit of peroxidase activity was defined as the amount of enzyme that 
caused an increase in absorbance of 0.01 per minute.

Lipid peroxide formation was studied by the Thibarbituric acid (TBA) colour reaction. Five $\mathrm{ml}$ of 0.5 percent TBA solution and $2 \mathrm{ml}$ of $1 \mathrm{~N} \mathrm{H}_{2} \mathrm{SO}_{4}$ were added to $50 \mathrm{mg}$ of embryo in a hard glass tube with close fitting glass lid. The mixture was thoroughly shaken and placed in an oven at $100^{\circ} \mathrm{C}$ for $1 \mathrm{~h}$. After cooling; $5 \mathrm{ml}$ of metholcellosolve was added and centrifuged at $2500 \mathrm{rpm}$ for $10 \mathrm{~min}$. The absorbance of the clear supernatant was measured in a LCD type JASCO spectrophotometer at 520nm (Bernheim et al., 1948). For Lipoxygenase extraction the enzyme was extracted using phosphate buffer $\left(\mathrm{pH} 6.5\right.$ ) at $4^{\circ} \mathrm{C}$ in a homogenizer (Virtis model 23) for 30 minute. The mixture was centrifuged at $25,000 \times \mathrm{g}$ for $15 \mathrm{~min}$ at $4^{\circ} \mathrm{C}$. The supernatant of $20 \mu \mathrm{l}$ was mixed with $30 \mu \mathrm{l}$ linoleic sodium $(25 \mathrm{mmol} / \mathrm{L}), \quad 2.95 \mathrm{ml}$ phosphate buffer $(0.2 \mathrm{~mol} / \mathrm{L}, \mathrm{pH} 9.0)$ at $30^{\circ} \mathrm{C}$. The Lipoxygenase activity was evaluated (OD 234/min x mg) 15 seconds later by measuring absorbance at $234 \mathrm{~nm}$ for every one minute (Hildebrand et al., 1991).

\section{Statistical analysis}

The analysis of variance for all the characters was worked out as suggested by Panse and Sukhatme (1967). The critical difference (CD) was worked out at 5 per cent probability level.

\section{Results and Discussion}

The sunflower seeds stored at cold storage conditions maintained the moisture content as that of the initial moisture content up to the end of storage period, while the seeds stored at ambient condition gained moisture content to the tune of 0.3 per cent increment at the end of storage period. In general increase in moisture content during storage leads to increase in the seed deteriorative changes which resulted in the loss of seed quality and viability. The sunflower seeds stored with 6 per cent moisture content maintained the seed quality parameters at higher level than the seeds with 8 per cent moisture content both under ambient and cold storage conditions. The seeds stored at $-20^{\circ} \mathrm{C}$ with low moisture content of 6 per cent recorded higher speed of germination, germination, maximum shoot and root length and vigour index than the seeds stored at ambient condition with 8 per cent moisture content irrespective of the storage conditions at end of ten months of storage.

The percentage increase of germination at cold storage $\left(-20^{\circ} \mathrm{C}\right)$ over ambient condition was 12 per cent. The seeds stored at $-20^{\circ} \mathrm{C}$ with low moisture content of 6 per cent recorded higher speed of germination $(90 \%)$ and the highest vigour index (4671) than the seeds stored at ambient condition with 8 per cent moisture irrespective of the storage conditions at the end of ten months of storage (Table 1). Similar result was recorded in sunflower seeds stored at low temperature which registered maximum germination than the seeds stored in ambient condition by Corbineau et al., (2002).

With reference to biochemical changes, the electrical conductivity of seed leachate, seed oil content, free fatty acid and enzymatic activity were evaluated. The electrical conductivity is a good indicator for the intensity of deterioration of seeds. In the EC test, seed quality is indirectly evaluated through the determination of the EC of the solution resulting from the soaking of seeds in water. The electrical conductivity recorded by the seed stored at ambient condition was the maximum $\left(0.264 \mathrm{dSm}^{-1}\right)$, while the seeds stored at $-20^{\circ} \mathrm{C}$ recorded the minimum $(0.178$ $\mathrm{dSm}^{-1}$ ) at the end of ten months of storage. This may be due to the less loss of membrane 
integrity to the seeds of cold storage than the seeds stored under ambient condition.

The seeds rich in oil have limited longevity due to their specific chemical composition. The oil content of the seeds decreased with advancement in storage period. Decrease in oil content with increase in storage period has been reported by Balasevic-Tubic et al., (2005) in soybean and sunflower.

In oil crops, such as sunflower, autooxidation of lipids and increasing the content of free fatty acids during storage period are the main reasons for rapid deterioration of seed of oil plants as announced by Balasevic-Tubic et al., (2005).

In the present study, the sunflower, groundnut and soybean seeds with 8 per cent moisture content stored at ambient condition registered the highest value of free fatty acid content $(0.319 \%)$. The seeds stored at $-20^{\circ} \mathrm{C}$ recorded lower value of free fatty acid content $(0.254$ $\%)$ than the seeds stored at ambient condition.

Many biochemical investigations have proven that lipid peroxidation and fat activity (free fatty acid percentage) are the major causes of seed deterioration, including cellular membrane disruption. As seed quality declined there was a concurrent increase in the levels of free fatty acids. In the present study with increase in free fatty acid contents there was a concurrent rise in seed leachate electrical conductivity suggesting that membrane integrity was declining.

Lipid peroxidation activity increased from initial month onwards in stored sunflower seeds. However there was a rapid increment in the lipid peroxidation activity in the seeds stored under ambient condition. However, there was a slight variation in the activity in the seeds stored at low temperature. With reference to storage conditions, the seeds stored at $-20^{\circ} \mathrm{C}$ maintained minimum lipid peroxidation activity (1.403 OD value), while the sunflower seed stored at ambient condition recorded maximum lipid peroxidation activity (0.707 OD value). Between the moisture contents, seeds stored with 6 per cent moisture content recorded the minimum lipid peroxidation activity (1.495 OD value) than the seeds stored with 8 per cent moisture content (1.518 OD value).

The measurement of enzymatic activity was one of the earliest biochemical technique tried to assess the deterioration of seed to predict seed germinability.

Certain enzymes lose their activity with loss of seed viability. However, individual seed differ in their enzyme activity depending upon the precursor available for synthesis of particular enzyme.

Catalase, peroxidase and lipoxigenase are the antioxidant enzymes and the activity of these enzymes was measured for the stored seeds of sunflower seeds stored at cold storage condition to determine the level of seed deterioration in comparison with the seeds of ambient storage (Fig. 1).

During aging, peroxidative changes may be the major cause of seed deterioration (Stewart and Bewly, 1980). Protective mechanisms that could scavenge the peroxidatively produced free radicals and peroxides have been reported in soybean (Sung, 1996). These protective mechanisms involve several free radical and peroxide-scavenging enzymes like superoxide dismutase, catalase, ascorbate peroxidase and peroxidase.

Loss of seed viability was also associated with decrease in catalase activity in sunflower by Bailly et al., (1996); Goel et al., (2003) in cotton. In the present investigation, the catalase activity decreased during storage. 
Table.1 Influence of seed moisture, temperature and period of storage on germination (\%) and vigour index of sunflower cv.CO 4

\begin{tabular}{|c|c|c|c|c|c|c|c|c|c|c|c|c|c|c|c|c|c|c|c|c|}
\hline \multirow{4}{*}{$\begin{array}{l}\text { Storage } \\
\text { periods } \\
\text { (P) }\end{array}$} & \multicolumn{10}{|c|}{ Seed moisture content (M) } & \multicolumn{10}{|c|}{ Seed moisture content (M) } \\
\hline & \multicolumn{5}{|c|}{$6 \%$} & \multicolumn{5}{|c|}{$8 \%$} & \multicolumn{5}{|c|}{$6 \%$} & \multicolumn{5}{|c|}{$8 \%$} \\
\hline & \multicolumn{10}{|c|}{ Storage temperature $(\mathbf{T})$} & \multicolumn{10}{|c|}{ Storage temperature $(T)$} \\
\hline & $\underset{\text { ent }}{\text { Ambi }}$ & $5^{0} \mathrm{C}$ & $-5^{0} \mathrm{C}$ & $\begin{array}{c}- \\
20^{0} \\
C\end{array}$ & $\begin{array}{c}\text { Mea } \\
\text { n }\end{array}$ & $\underset{\text { ent }}{\text { Ambi }}$ & $\begin{array}{l}5^{0} \\
\mathrm{C}\end{array}$ & $-5^{0} \mathrm{C}$ & $\begin{array}{c}- \\
20^{0} \\
\text { C }\end{array}$ & $\begin{array}{c}\text { Mea } \\
\mathbf{n}\end{array}$ & $\begin{array}{c}\text { Ambi } \\
\text { ent }\end{array}$ & $5^{0} \mathrm{C}$ & $-5^{0} \mathrm{C}$ & $\begin{array}{c}- \\
20^{0} \\
\mathrm{C}\end{array}$ & $\begin{array}{c}\text { Mea } \\
\mathbf{n}\end{array}$ & $\begin{array}{c}\text { Am } \\
\text { bien } \\
\mathbf{t}\end{array}$ & $5^{0} \mathrm{C}$ & $-5^{0} \mathrm{C}$ & $\begin{array}{c}- \\
20^{0} \\
\mathrm{C}\end{array}$ & Mean \\
\hline $\mathbf{0}$ & 90 & 90 & 90 & 90 & 90 & 88 & 88 & 88 & 88 & 88 & 4653 & 4653 & 4653 & 4653 & 4653 & 4452 & 4452 & 4452 & 4452 & 4452 \\
\hline 2 & 88 & 90 & 90 & 90 & 90 & 84 & 88 & 88 & 88 & 87 & 4180 & 4527 & 4635 & 4644 & 4497 & 3948 & 4418 & 4444 & 4453 & 4316 \\
\hline 4 & 84 & 89 & 90 & 90 & 88 & 81 & 88 & 88 & 88 & 86 & 3881 & 4477 & 4626 & 4644 & 4407 & 3588 & 4391 & 4418 & 4426 & 4206 \\
\hline 6 & 78 & 88 & 89 & 90 & 86 & 74 & 85 & 86 & 88 & 83 & 3401 & 4365 & 4521 & 4608 & 4224 & 3078 & 4123 & 4257 & 4409 & 3967 \\
\hline 8 & 72 & 86 & 88 & 89 & 84 & 70 & 84 & 86 & 86 & 81 & 3002 & 4128 & 4418 & 4521 & 4017 & 2761 & 3982 & 4223 & 4266 & 3808 \\
\hline 10 & 68 & 84 & 86 & 88 & 82 & 64 & 82 & 84 & 86 & 79 & 2706 & 3864 & 4188 & 4400 & 3790 & 2470 & 3608 & 3948 & 4223 & 3562 \\
\hline \multirow[t]{2}{*}{ Mean } & 80 & 88 & 89 & 90 & 87 & 77 & 86 & 87 & 87 & 84 & 3637 & 4371 & 4511 & 4671 & 4297 & 3445 & 4192 & 4354 & 4366 & 4089 \\
\hline & $\mathbf{P}$ & $\mathbf{M}$ & \multicolumn{2}{|c|}{$\mathbf{T}$} & $\mathbf{P} \mathbf{X} \mathbf{M}$ & MX T & \multicolumn{2}{|c|}{$\mathbf{P} \mathbf{X} \mathbf{T}$} & \multicolumn{2}{|c|}{ P X M X T } & $\mathbf{P}$ & \multicolumn{2}{|r|}{$\mathbf{M}$} & $\mathbf{T}$ & \multicolumn{2}{|c|}{ P X M } & $\mathbf{M X} \mathbf{T}$ & \multicolumn{2}{|c|}{$\mathbf{P X} \mathbf{T}$} & $\underset{\mathbf{T}}{\mathbf{X} \mathbf{M} \mathbf{X}}$ \\
\hline $\mathrm{CD}(\mathrm{P}=\mathbf{0 . 0 5})$ & $\begin{array}{c}1.85^{*} \\
*\end{array}$ & $\begin{array}{c}1.07 * \\
*\end{array}$ & \multicolumn{2}{|c|}{$1.51 * *$} & NS & NS & \multicolumn{2}{|c|}{$3.71^{* *}$} & \multicolumn{2}{|c|}{ NS } & $115^{* *}$ & & $66^{*}$ & $93 * *$ & \multicolumn{2}{|c|}{$162 * *$} & NS & \multicolumn{2}{|c|}{$230 * *$} & NS \\
\hline
\end{tabular}


Fig.1 Influence of seed moisture, temperature and period of storage on catalase, peroxidase and lipoxygenase activity of sunflower cv.CO 4
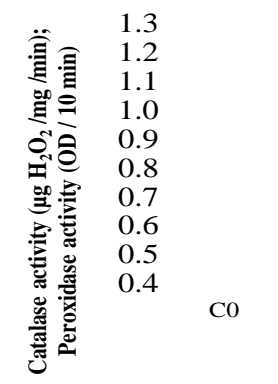

$\begin{array}{ccc}\mathrm{C} 1 & \mathrm{C} 2 & \mathrm{C} 3 \\ & \text { Initial } & \end{array}$

Co

Co

$\begin{array}{ll}\mathrm{C} 1 & \mathrm{C} 2 \\ 10 \mathrm{MAS} & -4\end{array}$

$\mathrm{C} 3$

$8 \%$ Seed moisture

$6 \%$ Seed
Catalase activity ( $\mu \mathrm{g} \mathrm{H} 2 \mathrm{O} 2 / \mathrm{mg} / \mathrm{min})$

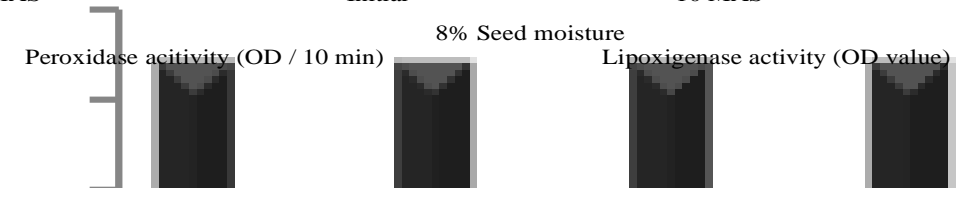

Fig.2 SEM image of 10 month stored seeds of sunflower cv.CO 4

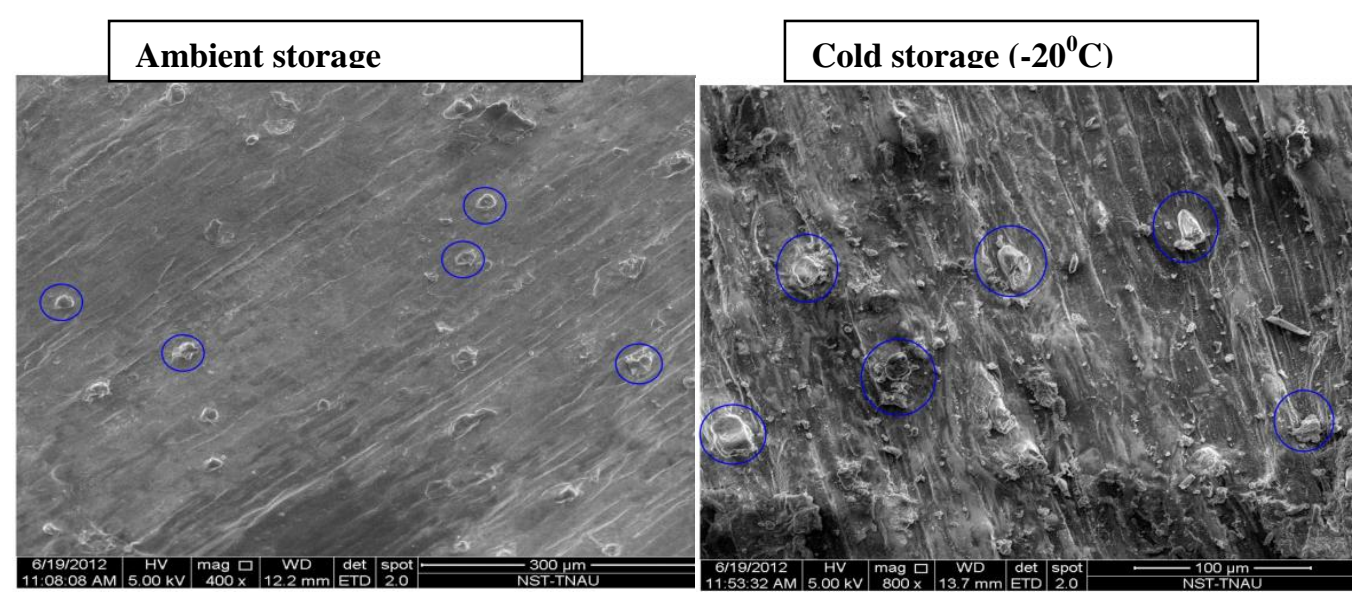

Encircled: Distribution of oil glands 
With reference to storage conditions, the seeds stored at cold storage $\left(-20^{\circ} \mathrm{C}\right)$ maintained maximum catalase activity $\left(1.02 \mu \mathrm{g} \mathrm{H}_{2} \mathrm{O}_{2} \mathrm{mg}^{-1}\right.$ $\min ^{-1}$ ), than the seeds at ambient condition $\left(0.81 \mu \mathrm{g} \quad \mathrm{H}_{2} \mathrm{O}_{2} \quad \mathrm{mg}^{-1} \min ^{-1}\right)$. Between the moisture contents, seeds stored with 6 per cent moisture content recorded the maximum catalase activity $\left(0.97 \mu \mathrm{g} \mathrm{H}_{2} \mathrm{O}_{2} \mathrm{mg}^{-1} \mathrm{~min}^{-1}\right)$ than the seeds stored with 8 per cent moisture content $\left(0.90 \mu \mathrm{g} \mathrm{H}_{2} \mathrm{O}_{2} \mathrm{mg}^{-1} \mathrm{~min}^{-1}\right)$. This was in line with the findings of Bao et al., (2011). He reported that antioxidant enzyme (Peroxidase and Catalase) activities were comparatively much lower with storage at room temperature than at $4^{\circ} \mathrm{C}$ after $6-12$ months.

The POD activity of sunflower seed decreased during storage from 0 to 10 months. The results of this study agree with the earlier observations of Sung and Jeng (1994) and Goel et al., (2003). The POD activity of peanut seed decreased during aging (Sung and Jeng 1994). Furthermore, these workers noted a good correlation between seed vigour and POD activity.

Oxidation of membrane bound and storage lipids by lipoxigenase would produce free fatty acid and free radicle, so lipoxigenase served as a measure of seed deterioration (Bailly et al., 2002). Lipoxygenase might be involved in seed deterioration (Bewley, 1986) because it catalyzes the incorporation of molecular oxygen into fatty acids containing a Z, Z-1, 4-pentadiene moiety and generates free radicals (Hatanaka et al., 1987; Vick and Zimmerman, 1987). The measurement of lipoxigenase activity in sunflower seed with 8 per cent moisture content recorded maximum lipoxigenase activity $(0.423$ $\left.\mathrm{g} \mathrm{mol} \mathrm{s}^{-1} \mathrm{mg}^{-1}\right)$ than the seeds stored with 6 per cent moisture content $\left(0.406 \mathrm{~g} \mathrm{~mol} \mathrm{~s}^{-1} \mathrm{mg}^{-1}\right)$. The seeds of sunflower stored at $-20^{\circ} \mathrm{C}$ recorded lower value of lipoxigenase activity $(0.348 \mathrm{~g}$ mol s${ }^{-1} \mathrm{mg}^{-1}$ ) than the seeds stored at ambient condition $\left(0.554 \mathrm{~g} \mathrm{~mol} \mathrm{~s}^{-1} \mathrm{mg}^{-1}\right)$ indicated the less deterioration changes at cold storage.

To study the, seed structural changes, the seed coat of seeds of cold storage $\left(-20^{\circ} \mathrm{C}\right)$ and ambient storage were examined under the scanning electron microscope (SEM). The changes in seed coat with reference to storage temperature revealed that in seeds of sunflower the seed coat changes were associated with the prominent changes expressed by the seeds in ambient condition was reduction in number and size of oil glands in sunflower (Figure 2). However, the seeds of cold storage expressed minimum seed coat changes at the end of storage period.

The study on seed health status for stored seed of sunflower revealed that, at cold storage conditions of $-20^{\circ} \mathrm{C}$ and $-5^{\circ} \mathrm{C}$, the fungal activity was nil, while seeds of ambient storage and cold storage of $5^{\circ} \mathrm{C}$ showed the symptom of infection with Aspergillus flavus and Rhizopus sp., the infection due to A. flavus was comparatively higher than Rhizopus sp. Aspergillus species were capable of reducing the fat and protein content. It was responsible for maximum depletion of fat content in all oil seeds such as safflower, soybean, sesamum and groundnut as reported by Ashok and Chavan (2011).

From the present study it can be concluded that, physiological changes such as reduction in the germination, root length, shoot length, vigour index and seedling dry weight with advancement in storage period was associated with changes in biochemical parameters such as reduction in protein, oil and enzyme activity, increase in free fatty acid, lipid peroxidation and lipoxygenase enzyme activity. The prominent structural changes expressed by the seeds in ambient condition were cell wall damage in sunflower seeds. All these changes related with seed quality deterioration were maintained at minimum in seeds under cold storage than the seeds under ambient storage which revealed the suitability of cold storage over ambient storage for sunflower seeds. The seeds of sunflower with 6 per cent moisture content stored at $-20^{\circ} \mathrm{C}$ maintained seed physiological and biochemical qualities at higher level with minimum structural changes up to ten months of storage. 


\section{References}

Ali-Khan, S.T and C.G. Young. 1973. Variation in protein content of field peas. Can. J. Pl. Sci., 53: 37-41.

Ashok, R.B. and A.M. Chavan. 2011a. Extracellular lipase enzyme production by seed-borne fungi under the influence of physical factors. Intern. J. of Biology., 3(1): 94-100.

Balasevic-Tubic,S., D. Malenneic, M. Tatic and J. Miladinovic. 2005. Influence of ageing process on biochemical changes in sunflower seed. Helia, 28: 107-114.

Bernheim, F., M.L.C. Bernheim and K.M. Wilbur. 1948. The reaction between thiobarbituric acid and the oxidation products of certain lipids. J. Biol. Chem., 114: 257-264.

Christiansen, M. K and R.D. Moore. 1961. Temperature in viva hydrolysis of cotton seed oil. Crop Sci., 1: 285-286.

Corbineau, F., C. Gay-Mathieu, D. Vinel and D. Come. 2002. Decrease in sunflower (Heliantus annuus) seed viability caused by high temperature as related to energy metabolism membrane damage and lipid composition. Physiol. Plant., 116: 489-496.

Goel, A., A.K. Goel and I.S. Sheoran. 2003. Changes in oxidative stress enzymes during artificial aging in cotton (Gossypium hirsutum L.) seeds. J. Plant Physiol., 160:1093-1100.

Gwinner, J., R. Harnisch, O. Müch. 1996. Manuel sur la manutention et la conservation des grains après-récolte. GTZ, Eschborn, Germany. p 368.

Hatanaka A., T. Kajiwara and J. Sekiya. 1987. Biosynthesis pathway for C6-aldehydes formation from linolenic acid in green leaves. Chem. Phys. Lipids, 44: 341-361.

Hildebrand, A.R., G.T. Penfield, D.A. Kring, M. Pilkington, Z.A. Camargo, S. Jacobsen and W.V. Boynton. 1991. Chicxulub crater: A possible cretaceous - tertiary boundary impact crater on the Yucatan Peninsula, Mexico. Geology, 19: 867-871.

Koostra, P.T. and J.F. Harrington. 1969. Biotechnical effects of age on membrane lipids of Cucumis sativus L. seed. Proc. International Seed Test. Assoc., 34: 329340.

Panse, V.G. and P.V. Sukhatme. 1967. Statistical methods for Agricultural workers. ICAR Pub., New Delhi.

Roberts, E.H. 1972. Storage environment and the control of viability, In: Viability of seeds (Ed: E.H. Roberts). Chapman and Hall, London, UK, pp. 14-58.

Sadasivam, S. and A. Manickam. 1995. Proteins and enzymes, In: Biochemical methods for agricultural sciences, Wiley Eastern Ltd., New Delhi. pp. 33-143.

Sisman, C.B. 2005. Quality losses in temporary sunflower seed stores and influences of storage conditions on quality losses during storage. Central European Agri., 6(2): 143150.

Stewart, R.R.C. and J.D. Bewley. 1980. Lipid peroxidation associated with accelerated ageing of soybean axes. Plant Physiol., 65: 246-248.

Sung J.M. and T.L. Jeng. 1994. Lipid peroxidation and peroxide-scavenging enzymes associated with accelerated aging of peanut seed. Physiol. Plant., 9: 51-55

Sung, J.M. 1996. Lipid peroxidation and peroxide scavenging in soybean seeds drying ageing. Physiological Plantarum, 97: 85-89.

Vick, B.A. and D.C. Zimmerman. 1987. Oxidative systems for the modification of fatty acids. In: The Biochemistry of Plants, (Ed: P.K. Stumpf, E.E. Conn) Vol 9. Academic Press, New York, pp 53-90.

Vijay D, M. Dadlani, P.A.Kumar and S.K.Panguluri. 2009. Molecular Marker Analysis of Differentially Aged Seeds of Soybean and Safflower. Plant Molecular Biology Reporter, 27: 282-291.

\section{How to cite this article:}

Nithya, N., J. Renugadevi, M. Bhaskaran and Johnjoel, A. 2017. Influence of Temperature and Moisture on Seed Viability Period in Sunflower Seeds. Int.J.Curr.Microbiol.App.Sci. 6(12): 820-827. doi: https://doi.org/10.20546/ijcmas.2017.612.087 